\title{
Evaluating Growth, Seed Yield and Yield Attributes of Camelina (Camelina sativa $L$ ) in Response to Seeding Rate and Nitrogen Fertilizer Levels Under Irrigation Condition, Southern Ethiopia
}

\author{
Daniel Manore $^{1, *}$, Ashenaf Yohanns ${ }^{2}$ \\ ${ }^{1}$ Department of Plant Science, College of Agriculture, Wachemo University, Hossana, Ethiopia \\ ${ }^{2}$ Department of Natural Resource Management, College of Agriculture, Wachemo University, Hossana, Ethiopia
}

Email address:

danimanore@gmail.com (D. Manore)

${ }^{*}$ Corresponding author

\section{To cite this article:}

Daniel Manore, Ashenaf Yohanns. Evaluating Growth, Seed Yield and Yield Attributes of Camelina (Camelina sativa L) in Response to Seeding Rate and Nitrogen Fertilizer Levels Under Irrigation Condition, Southern Ethiopia. Agriculture, Forestry and Fisheries. Vol. 8, No. 2, 2019, pp. 31-35. doi: 10.11648/j.aff.20190802.11

Received: December 27, 2018; Accepted: January 25, 2019; Published: May 7, 2019

\begin{abstract}
Camelina sativa (L.) Crantz is an ancient oilseed crop. Camelina seed can be used as a food ingredient and raw material for the production of oil. The by-product of camelina oil used as fodder ingredient. But there is no information in Ethiopia about camelina production, so that an experiment was conducted at at Lambuda Hossana area, Southern Ethiopia to investigate the effect of different levels of nitrogen fertilizer on the yield and yield attribute along with different seeding rate of camelina in 2016 cropping year. The treatments were 0,50,100 and $150 \mathrm{~kg} \mathrm{ha}^{-1}$ and Camelina seeding rate 5, 7.5, 10 and 12.5 $\mathrm{kg} \mathrm{ha}^{-1}$. The experiment was laid out in RCBD design with three replications. The result revealed that application of nitrogen has significantly increased the seed yield camelina compared with the control. There was a steady increase in the seed yield of camelina for nitrogen levels from $100 \mathrm{~kg} \mathrm{ha}^{-1}$ up to $150 \mathrm{~kg} \mathrm{ha}^{-1}$ in the studyarea. Combined analysis of the two treatment factors data showed that still the highest yield was obtained at nitrogen level applied at of $150 \mathrm{~kg} \mathrm{ha}^{-1}$ with seeding $10 \mathrm{ha}^{-1}$. Seeding rate also varied significantly in their performance with respect to yield components and yield $\mathrm{ha}^{-1}$. Accordingly, $10 \mathrm{~kg}$ $\mathrm{ha}^{-1}$ performed best relative to the other three seeding rate. It is concluded that there is a significant and positive response of camelina to applied nitrogen and the highest biological and grain yield was obtained at nitrogen level of $150 \mathrm{~kg} \mathrm{ha}^{-1}$ with seeding rate of $10 \mathrm{~kg} \mathrm{ha}^{-1}$. Thus it is recommended that nitrogen fertilizer should be applied in the area to mitigate nitrogen deficiency for enhanced camelina yield.
\end{abstract}

Keywords: Camelina, Nitrogen Fertilizer, Seeding Rate

\section{Introduction}

Camelina sativa (L.) Crantz., like canola and mustard, is a member of the Brassicaceae family. It is also commonly referred to as false flax due to the similarity in pods/bolls. It originated in the Mediterranean-Central Asian region. It is an annual or winter annual that grows upto $90 \mathrm{~cm}$ tall and has branched smooth or hairy woody stems. Leaves are arrowshaped, sharp-pointed, five to eight $\mathrm{cm}$ long with smooth edges. The flowers are small, pale or greenish yellow with four petals and predominantly self-pollinated. The pear-like seed pods (siliques) are six to $14 \mathrm{~mm}$ long holding eight to ten yellow or brownish yellow seeds. It can grow on a wide range of soil types, and is responsive to fertilizer application similar to canola and mustard. The soil nutrient requirements of camelina are similar to those of other Brassica crops with the same yield potential. Camelina has been shown to respond to nitrogen $(\mathrm{N})$ similarly to mustard or flax. However, it can yield well with lower nutrient inputs and observed no yield increases beyond $60 \mathrm{~kg} \mathrm{~N} / \mathrm{ha}$ in Nova Scoti [1]. While at a site in Prince Edward Island yield increases were observed up to $120 \mathrm{~kg}$ $\mathrm{N} / \mathrm{ha}$, seed yield increases beyond $80 \mathrm{~kg} \mathrm{~N} / \mathrm{ha}$ were not 
significant. In Oregon (USA), no increases in yield were observed beyond $50 \mathrm{~kg} \mathrm{~N} / \mathrm{ha}$ [2]. Research clearly demonstrates that the fertilizer requirement and response in camelina varies with soil and growing conditions. Other nutrient requirements for camelina are similar to those of other Brassica species. However, there has been relatively little research conducted on this crop in Ethiopia, and its full agronomic practice remains largely unexplored. Studies in Saskatchewan [3] showed that camelina yields are comparable to those of other Brassica species. Camelina yields tend to be lower than the other species under adequate precipitation conditions. However, camelina out-yielded other Brassica species when nitrogen fertilizer was limiting. Seeding rate is also important as seed yield, maturity and competition with weeds are highly dependent on the plant stand. The soil nutrient requirements of camelina are similar to those of other Brassica crops with the same yield potential. Camelina has been shown to respond to nitrogen similarly to mustard or flax. There is no information available regarding seeding rate and nitrogen fertilizer level in Hossana area; to handle this problem objectives were initiated to increase the production of Camelina sativa (L.) Crantz through identification and use different seeding rate and nitrogen fertilizer levels and to study the yield responses in combination of nitrogen fertilizer levels and camelina seeding rate at Hossana area, Southern Ethiopia

\section{Materials and Methods}

\subsection{Description of Area}

The experiment was conducted at Wachemo University experimental site at Lambuda during 2016 cropping season from November to February. It lays an altitude of 1200-1800 Masl. The area receives a mean annual rain fall of $1200 \mathrm{~mm}$ with mean maximum temperature of $17-28^{\circ} \mathrm{C}$.

The experiment comprised of 16 treatments made up of a factorial combination of two input factors [four level of nitrogen fertilizer $(0,50,100$ and $150 \mathrm{~kg} / \mathrm{ha})$ and four types of seeding $(5,7.5,10$ and $12.5 \mathrm{~kg} / \mathrm{ha})$. The list of treatment combinations used in the experiment is shown in Table 1.

Table 1. Treatment combinations of phosphorous level and seeding rate.

\begin{tabular}{lllll}
\hline Nitrogen kg & \multicolumn{5}{l}{ Camelina rates per hectare } \\
\cline { 2 - 5 } per ha & $\mathbf{5}$ & $\mathbf{7 . 5}$ & $\mathbf{1 0}$ & $\mathbf{1 2 . 5}$ \\
\hline 0 & 0,5 & $0,7.5$ & 0,10 & $0,12.5$ \\
50 & 50,5 & $50,7.5$ & 50,10 & $50,12.5$ \\
100 & 100,5 & $100,7.5$ & 100,10 & $100,12.5$ \\
150 & 150,5 & $150,7.5$ & 150,10 & $150,12.5$ \\
\hline
\end{tabular}

\subsection{Field Layout}

The experimental design was factorial experimental design by using RCBD with Four types of seeding rate and four levels of phosphorous fertilizer with three replications the seed were sown directly in rows with spacing of $5 \mathrm{~cm}$ between rows and with drilling seeds. Three seeds per hill was planted in each row and thinned to a single plant per hill after two weeks of germination to maintain the plant population in each treatment.

\subsection{Data to Be Collected}

Soil sampling and analysis: Soils were sampled from a depth of a depth of $30 \mathrm{~cm}$ ) at 10 random points in the field and soil analysis was conducted from a composite sample. The soil was sampled following the same procedure, but according to the treatments, after crop harvest. samples from a composite of each treatment was used for analysis of different soil parameters including $\mathrm{pH}$, available phosphorous and soil nitrogen was estimated by alkaline permanganate oxidation method [4]. Available Phosphorous was determined by Olsen's method [5], using spectrophotometer (660 nm wave length). Organic carbon was determined by Walkely and Black wet oxidation [6]. The $\mathrm{pH}$ was determined by the electrometric method in a soil suspension with a soil/water ratio of 1:2.5.

\subsubsection{Crop Phenology and Growth Parameters}

Days of emergence, from days of sowing to $50 \%$ emergence was recorded, similarly $50 \%$ days of flowering was recorded after $50 \%$ of flowers appeared in plants. Plant heights $(\mathrm{cm})$, were measured at mid flowering, and from the base of the plant to tip of the main stem. Number of branches born on the main stem of plant was counted and averaged to represent number of branches per plant

\subsubsection{Dry Matter Production}

Ten randomly selected plants (destructive sampling) used for nodulation parameters were taken to record dry matter production at $50 \%$ flowering stage. The sampled plants were separated in to leaves and stem. These samples were sundried until constant weight was obtained.

\subsubsection{Yield and Yield Components}

Plants selected from net plot area were used for recording yield components.

Number of pods per plant: Total filled pods present in five tagged plants were counted and the mean was calculated and expressed as number of pods per plant.

Number of seeds per pod: From a random sampled five pods of each plant, the seeds from pods were separated, counted and mean number of seeds per pod was calculated.

Grain yield (tone ha ${ }^{-1}$ ): After harvest plants from the net plot area were allowed to dry in sun and adjusted at $10 \%$ content and converted in tone per ha.

\subsection{Statistical Analysis}

Data collected on various characters or parameters were subjected to Analysis of Variance (ANOVA) using general liner model SAS ${ }^{\circ},(2002)$ Software. Mean separations were done using LSD (5\%)[7]. Analysis of variance (ANOVA) was considered to test for significant differences among treatment means.

\section{Result and Discussion}

\subsection{Physico-chemical Analysis of Experimental Site}

Soil analysis before planting 
Soil samples collected before planting and after crop harvesting. The analytical results indicated that the textural class of the experimental site soil was silt loam with a proportion is shown in figure 1 .

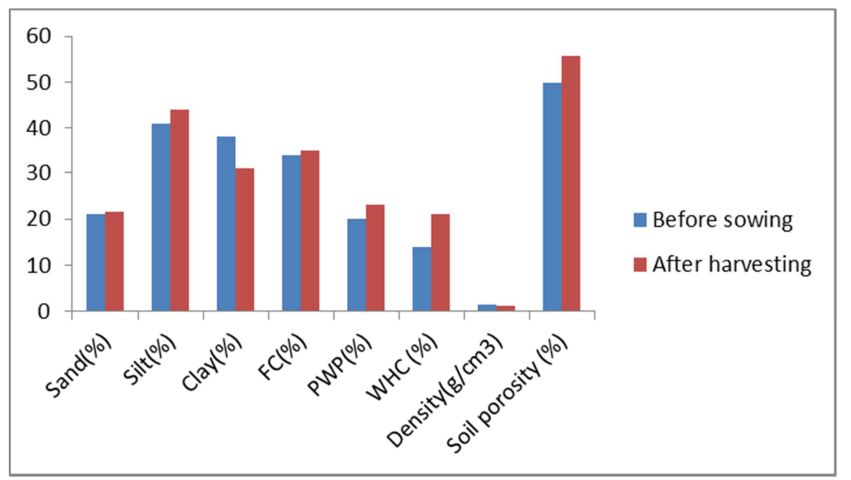

Figure 1. Soil Physical properties study area.

Available water content values in the study site in before sowing and after crop harvesting were rated as high [8]. This reveals that in general, the higher the percentage of silt and clay sized particles, the higher the water holding capacity. The small particles (clay and silt) have a much larger surface area than the larger sand particles. This large surface area allows the soil to hold a greater quantity of water. The amount of organic material in a soil also influences the water holding capacity. As the level of organic matter increases in a soil, the water holding capacity also increases due to the affinity of organic matter for water. The Soil bulk density showed variation before sowing and after harvesting in in the study area which good for agricultural crop production [9]. This divulges that the bulk density of study sites was within good range for agriculture and that no excessive compaction and no restriction to root development. The ideal total pore space values, which are acceptable for crop production, are around $50 \%$ [10]. This reveals that the total porosity of the study site soil was acceptable for crop production with its good aeration, water movement, microbial activity and root penetration. This reveals that the soil porosity was affected directly by soil organic matter.

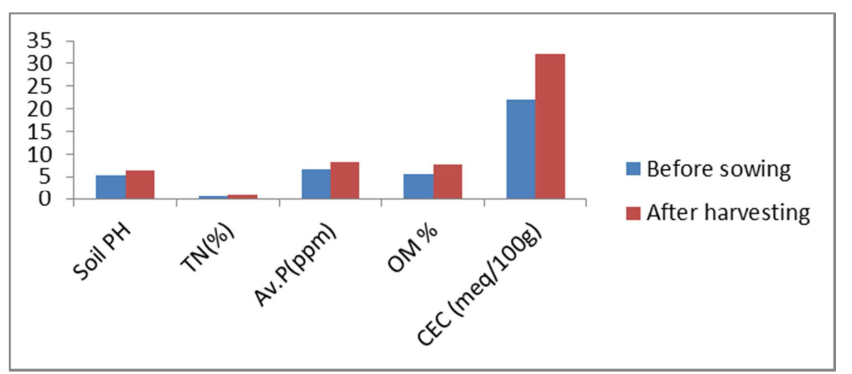

Figure 2. Soil chemical properties study area.

The soil was acidic before sowing and moderately acidic after harvesting in the study site [11]. Soils with $\mathrm{pH}$ values of less than 5.5 are deficient in $\mathrm{Ca}$ and/or $\mathrm{Mg}$ as well as Phosphorou [12]. These values reveal the absence of calcium carbonate in the study area, where values of $\mathrm{pH}-\mathrm{H}_{2} \mathrm{O}$ less than 6.5 are generally considered as non-calcareous or the soil was not affected by salt. The total nitrogen content of soils at Lambuda is categorized under the optimum level after harvesting and high level before sowing [13]. This indicates that organic matter is the main sources of nitrogen, thus the need to maintain the organic matter content through organic matter management methods, such as incorporating crop residues to the soil, is important. The results are in accordance with the findings reported that intensive and continuous cultivation forced oxidation of organic carbon and thus resulted in reduction of total nitrogen [14]. As revealed the result of soil test in total nitrogen content was reduced from before sowing to after harvesting in study site due to intensive and continuous cultivation, leaching and crop removal. The soil samples were analyzed for soil available phosphorous ( $\mathrm{ppm}$ ) parameters with values of before sowing and after harvesting 6.7 and 8.2, respectively, which were shown in figure 2. The soil available phosphorous (ppm) value was rated very low in the study area [11]. In tropical soils, large quantities of soil Phosphorous in mineral form are not readily available for absorption by the plant. This phosphorus occurs in numerous combinations with iron and aluminium in most of well weathered tropical soils, such as in the present study area. The phosphorus content in soil solution is low as compared to other nutrients such as nitrogen, potassium, calcium and magnesium [15]. Many soils fix large quantity of phosphorus by converting readily soluble phosphorus to forms less available to plants in the above combinations. According to the ratings for some tropical soils [16], available Phosphorous contents in the study sites is very low in experimental site.

\subsection{Effect of Nitrogen Fertilizer Level and Seeding Rate on Phenological Growth}

\subsubsection{Intercultural Operations and Management}

After seedling emergence, irrigation (10 litres per plot) was carried out daily by water cans until emergence. There after, irrigation with same amount of water was carried out on alternate days at every 4th day until pod setting. Weeding was done manually as and when required. Harvesting was carried out after 118 days of seeding (i.e., February 2017) when $70 \%$ silicles turned light-brown in color. Harvested biomass was shade dried for four days and threshed by hand.

\subsubsection{Plant Height and Number of Branches and Seeds Per Pod}

Plant height was recorded between $58.7 \mathrm{~cm}$ (control) and $73.1 \mathrm{~cm}$ with seeding rate of $10 \mathrm{~kg} \mathrm{ha}^{-1}$ (Table 2). Although variations in plant height were observed among the treatments, not all the treatments were significantly $(\mathrm{P}<$ $0.05)$ different from each other. Addition of $\mathrm{N}\left(100 \mathrm{~kg} \mathrm{ha}^{-1}\right)$ and $10 \mathrm{~kg} \mathrm{ha}^{-1}$ has significantly influenced plant height over control. Improvement in growth of camelina has been observed with nitrogen fertilization (50-150 kg ha $\left.{ }^{-1}\right)$ and with seeding rate of $10 \mathrm{~kg}$ per hectare [17]. Number of branches plant- ${ }^{1}$ was recorded from 6.5 (control) to $9.4 \mathrm{~cm} 100 \mathrm{~kg}$ per 
hectare (Table 2). In camelina, who observed significant increase in number of branches plant ${ }^{1}$ in presence of nitrogen fertilizer. Number of silicles pods-1 ranged between 9 (control) and 12 with applications of $100 \mathrm{~kg}$ per hectare at 12.5 seeding rate positive and synergistic effects of nitrogen and sulfur on number of branches in camelina are well documented [18]. Perhaps due to this phenomenon, the dose of $\mathrm{N}\left(100 \mathrm{~kg} \mathrm{ha}^{-1}\right)$ applied in the present study was not sufficient enough to get synergize with phosphorous and promote plant growth.

\subsection{Yield and Yield Attributing Traits}

Number of seeds per pod was recorded between 11.9 with $100 \mathrm{~kg} \mathrm{ha}^{-1}$ and 12 in $150 \mathrm{~kg} \mathrm{ha}^{-1}$, so the differences among the treatments were significant $(\mathrm{P}<0.05)$ (Table 2). Number of seeds pods per plant in the present study broadly fell within the range reported by different researchers in camelina [19]. Crop matured in 118 days after seeding relatively earlier in comparison to the crop maturity period (i.e., 105 to 234 days) in camelina as reported by [20] in their study conducted in cold and temperate Mediterranean climate in Chile. Shorter crop maturity period in the study was perhaps due to the hotter climate of our study site. Seed yield increased significantly $(\mathrm{P}<0.05)$ by addition of $\mathrm{N}(100 \mathrm{~kg}$ $\mathrm{ha}^{-1)}$ and $10 \mathrm{~kg} \mathrm{ha}^{-1}\left(3.2\right.$ tone $\left.\mathrm{ha}^{-1}\right)$.

Nitrogen positively affects number and weight of pods and seed and flowers per plant and thus promote seed yield [20]. In camelina, increase in seed yield with increased nitrogen, fertilization has already been reported wide variation in seed yield has been reported ranging from $420 \mathrm{~kg} \mathrm{ha}^{-1}$ to $2314 \mathrm{~kg}$ $\mathrm{ha}^{-1}$ in camelina cultivated at different locations in Chile [21] although camelina is reported to exhibit adaptability to different climates and soil. Particularly discussing the patterns of seed yield of camelina cv. Calena in the Indian context, seed yield ranging from 226.7 to $458.9 \mathrm{~kg} \mathrm{ha}^{-1}$ [22]. Seed yield of the accessions tested ranged from 1,638 to $3106 \mathrm{~kg} \mathrm{~kg} \mathrm{ha}^{-1}$ over two locations in the Saskatoon area. In Alberta, camelina seed yield ranged from 1,987 to $3,320 \mathrm{~kg}$ $\mathrm{ha}^{-1}$ over two locations near Beaverlodge. In the [23] observed seed yield ranging from 1,096 to $1,660 \mathrm{~kg} \mathrm{ha}^{-1}$ over two locations and two seasons, in view of this, seed yield in the present study was considerable indicating promising potentials of cultivating camelina in Southern Ethiopia. Although Nitrogen is reported to increase seed yield in different plants of Brassicaceae family [24].

Table 2. Effects of Nitrogen fertilizer level and seeding rate on phenology and yield attributes of camelina.

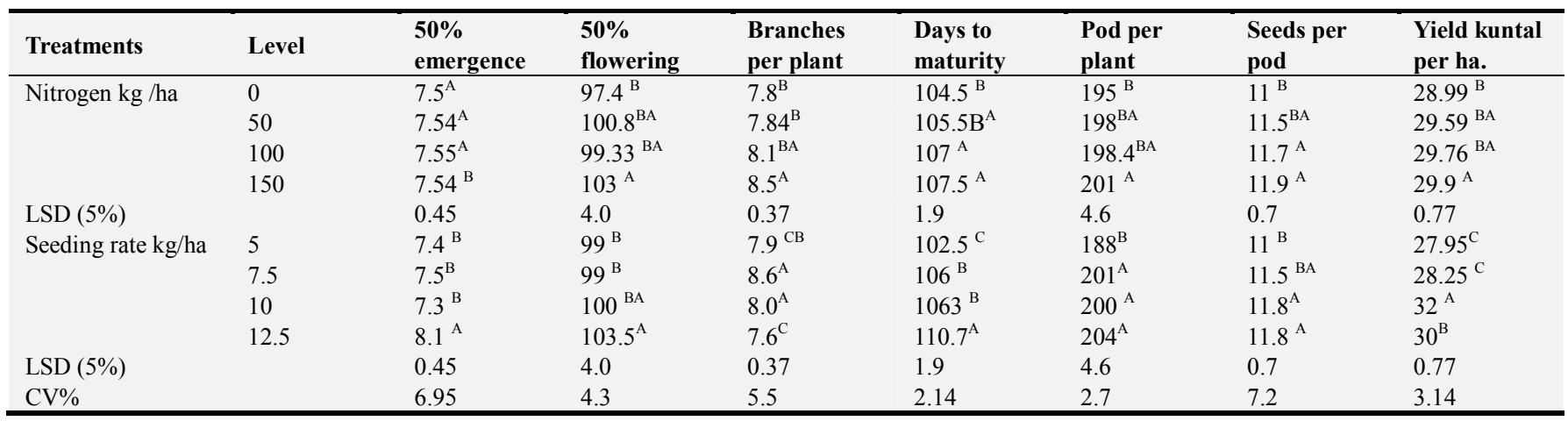

Mean values within column followed by the same letter are not significantly different $(\mathrm{p} \leq 0.05)$, NS = non significant at $5 \%$ probability level, $\mathrm{n}=48$ (Number of observation for each parameter $* * * *, * *=$ Significant at $5 \%, 1 \%$ and $0.1 \%$ probability level

\section{Conclusion}

This study focused on four level of seeding rate of camelina seed with four level of nitrogen fertilizer and planted under irrigation condition using with completely randomized block design. Accordingly the seeding rate responded significantly, especially 7.5 and $10 \mathrm{~kg} / \mathrm{ha}$ was higher yield and yield components and also nitrogen levels responded very well with varied rates, 100 and $150 \mathrm{~kg} / \mathrm{ha}$ were statically performed best at all growth parameters and yield components. This research works were done in one year with single agro ecology at irrigation. The same treatment should be done at different cropping season at different location.

\section{Acknowledgements}

We have many thanks for Wachemo university research and community service office for financial support towards this research is acknowledged. We wish to express our gratitude to college of agriculture department of plant science.

\section{Abbreviation}

$\begin{array}{ll}\text { Acronym } & \text { Descriptions } \\ \text { ANOVA } & \text { Analysis of variance } \\ \text { CV } & \text { Coefficient of variation } \\ \text { FC } & \text { Field capacity } \\ \text { ha } & \text { hectare } \\ \text { LSD } & \text { Least Significant Difference } \\ \text { OM } & \text { Organic matter } \\ \text { RCBD } & \text { Randomized Complete block design } \\ \text { SAS } & \text { Statistically Analysis Software } \\ \text { WHC } & \text { Water holding capacity }\end{array}$




\section{References}

[1] Urbaniak, S. D., Caldwell, C. D., Zheljazkov, V. D., Lada, R. And Luan, L. 2008. The effect of cultivar and applied nitrogen on the performance of camelina sativa L. in the Maritime Provinces of Canada. Can. J. P1. Sci. 88: 111-119.

[2] C. and Phelps, S. 2009. Update on camelina agronomy research trials. Presentation at the Camelina Workshop, AAFC Research Station, Saskatoon, SK.

[3] Gugel, R. K. and Falk, K. C. 2006. Agronomic and seed quality evaluation of camelina sativa in western Canada. Can. J. P1. Sci. 86: 1047-1058.

[4] Subbaiah, B. V. and Asija, G. L., A rapid procedure for the estimation of available nitrogen in soil. Curr. Sci., 1956, 25: 259 .

[5] Jackson, M. L., Soil chemical analysis. Prentice Hall of India Pvt. Ltd., New Delhi., 1967.

[6] Jackson. M. L. 1958. Soil Chemical Analyses. Prentice Hall, Inc., Englewood Cliffs, New Jersy. pp 183-204.

[7] Gomez. K. A and Gomez A. A. 1984. Statistical procedures for agricultural research. $2^{\text {nd }}$ editions.

[8] Shirazi, M. A., Boersma, L. Johnson, C. B., 2001. ParticleSize Distributions: Comparing TextureSystems, Adding Rock, and predicting Soil Properties. Soil Sc. Am. J. 65, 300-310.

[9] Hillel. (1980) Soil compaction is defined as a change in soil volume leading to increased soil bulk density and Soil compaction reduces air P1. Sci.: 110-115.

[10] Brady N. C. and R. R. Weil.2002. The Nature and Properties of Soils (13th ed). PearsonEducation Ltd., USA. 960p.

[11] Ethiosis (Ethiopia Soil Information System). Soil fertility status and fertilizer recommendation atlas for Tigray regional state, Ethiopia. Ethiopia; 2014.

[12] Mamo T, Hanque I, Kamara GS. Phosphorus status of some Ethiopian high land soils in proceeding of management of vertisolias in sub Saharan Africa. International live sock center for Africa, Adis Ababa, Ethiopia; 1998.
[13] Havlin, J. L., J. D. Beaton, S. L. Tisdale, W. L. Nelson (1999). Soil Fertility and Fertilizers Prentice Hall, New. pp. 345-355.

[14] Wakene Negassa and Heluf Gebrekidan. 2003. Forms of Phosphorus and status of available micronutrients under different land-use systems of alfisols in Bako area of Ethiopia. Ethiopian Journal of Natural Resources 5: 77-37.

[15] Tisdale, S. L., W. L. Nelson, J. D. Beaton and J. L. Havlin, 1995. Soil Fertility and Fertilizers. Prentice-Hall of India, New Delhi, India.

[16] Olsen, S. R., Cole, V., Walanbe, C. V. and Dean L. A. (1954). Estimation of Available phosphorus in soils by extraction with Sodium Bicarbonate. USA Circular NO 939.

[17] Zubr, J. and B. Matthäus. 2002. Effects of growth conditions on fatty acids and tocopherols in Camelina sativa oil. Ind. Crops Prod. 15: 155-162.

[18] Gesch, R. W., H. L. Dose and F. Forcella. 2017. Camelina growth and yield response to sowing depth and rate in the northern Corn Belt USA. Ind. Crop Prod. 95: 416-421.

[19] Koncius, D. and D. Karcauskiene. 2010. The effect of nitrogen fertilizers, sowing time and seed rate on the productivity of Camelina sativa. Zemdirbyste. 97 (4): 37-46.

[20] Jiang, Y. and C. D. Caldwell. 2016. Effect of nitrogen fertilization on Camelina seed yield, yield components, and downy mildew infection. Can. J. Plant Sci. 96: 17-26.

[21] Afshar, R. K., Y. A. Mohammed and C. Chen. 2016. Enhanced efficiency nitrogen fertilizer effect on camelina production under conventional and conservation tillage practices. Ind. Crop Prod. 94: 783-789.

[22] Zubr, J. 2003b. Qualitative variation of Camelina sativa seed from different locations. Ind. Crops Prod. 17: 161-169.

[23] Wang, S., M. Kreuzer, U. Braun and A. Scharm. 2017. Effect of unconventional oilseeds (safflower, poppy, hemp, Camelina) on in vitro ruminal methane production and fermentation. J. Sci. Food. Agric. 97: 3864-3870.

[24] Toncea, I. 2014. The seed yield potential of Camelia - first Romanian cultivar of Camelina (Camelina sativa L. Crantz). Rom. Agric. Res. 31: 17-23. 